\title{
Strategi Pendidik Anak Usia Dini Era Covid-19 dalam Menumbuhkan Kemampuan Berfikir Logis
}

\author{
La Hewi ${ }^{\circledR}$, Linda Asnawati² \\ 1Pendidikan Islam Anak Usia Dini, Institut Agama Islam Negeri Kendari \\ 2Pendidikan Anak Usia Dini Sultan Qaimuddin Kendari \\ DOI: $\underline{10.31004 / o b s e s i . v 5 i 1.530}$
}

\begin{abstract}
Abstrak
Penelitian ini bertujuan untuk mendeskripsikan strategi pendidik anak usia dini dalam melaksanakan tugas-tugasnya pada masa pandemi coronavirus disease atau covid-19. Peneliti menggunakan pendekatan kualitatif dengan metode studi kasus untuk memperoleh pemahaman tentang strategi pendidik anak usia dini dalam mengembangkan kemampuan berfikir logis pada anak. Teknik pengumpulan data yang digunakan adalah wawancara dan dokumentasi. Data yang dikumpulkan selanjutnya dianalisis dengan menggunakan interaktif model dengan langkah-langkah analisis data yaitu reduksi data, penyajian data, penarikan kesimpulan dan verifikasi. Hasil penelitian menunjukkan bahwa pertama, ada perubahan strategi pelaksanaan tugas guru PAUD yaitu sebagai perencana dan penilaian hasil pembelajaran sedangkan untuk tugas pelaksana pembelajaran guru PAUD dibantu oleh pendidik di rumah (orang tua) peserta didik; kedua, strategi pendidik PAUD di rumah dalam mengembangkan kemampuan berfikir logis anak yaitu anak diajak untuk memahami mengapa sekolah di rumah, mengapa keluar rumah harus menggunakan masker, kenapa tidak bisa bermain di luar rumah menggunakan metode dialog (percapakan /diskusi) dan keteladanan.
\end{abstract}

Kata Kunci: strategi; pendidik; anak usia dini.

\begin{abstract}
This study aims to describe the strategies of early childhood educators in carrying out their duties during the pandemic coronavirus disease or covid-19. Researchers used a qualitative approach with the case study method to gain an understanding of early childhood educator strategies in developing logical thinking skills in children. Data collection techniques used were interviews and documentation. The collected data is then analyzed using an interactive model with the steps of data analysis namely data reduction, data presentation, drawing conclusions and verification. The results showed that firstly, there was a change in the strategy of implementing PAUD teacher tasks, namely as a planner and assessment of learning outcomes while for the task of implementing PAUD teacher learning aids by the home educator (parents) of students; secondly, PAUD educator strategies at home in developing children's logical thinking abilities, that is, children are invited to understand why school at home, why go out of the house must use a mask, why can't play outside the house using the method of dialogue (conversation/discussion) and exemplary.
\end{abstract}

Keywords: strategy; educators; early childhood.

Copyright (c) 2020 La Hewi, Linda Asnawati

$\triangle$ Corresponding author:

Email Address : lahewih15@gmail.com (Jl. Sultan Qaimuddin No. 17 Baruga)

Received 8 May 2020, Accepted 17 May 2020, Published 19 May 2020 


\section{PENDAHULUAN}

Pandemi covid-19 mempengaruhi semua aktivitas kehidupan manusia mulai aktivitas olahraga, perkantoran, bahkan sampai pada hubungan transedental bagi seluruh pemeluk agama di dunia tidak terkecuali dengan bidang pendidikan. Aktivitas pendidikan yang sangat lekat dengan interaksi yang melibatkan banyak orang; pendidik dengan para peserta didik dalam satu lingkungan belajar secara langsung bertatap muka. Karena pandemi covid-19 interaksi secara langsung dihentikan (social distancing) dan diganti dengan aktivitas pembelajaran jarak jauh (daring) dengan memanfaatkan media internet. Hal ini berlaku untuk seluruh jenjang pendidikan mulai dari pendidikan tinggi, pendidikan menengah, sekolah dasar maupun untuk pendidikan anak usia dini. Lembaga-lembaga PAUD yang sangat intens dalam melakukan stimulasi perkembangan anak usia dini melalui kegiatan bermain sambil belajar di ruang-ruang kelas, karena adanya covid-19 diganti dengan pembelajaran di rumah masing-masing peserta didik.

Pendidikan anak usia dini sebagai jenjang pendidikan sebelum pendidikan dasar memberikan layanan pada anak sejak lahir hingga usia enam tahun dengan memberikan stimulasi berupa pemberian rangsangan pendidikan supaya menunjang pertumbuhan dan perkembangan jasmani serta rohani anak sehingga memiliki keterampilan untuk melanjutkan pada jenjang pendidikan selanjutnya yaitu sekolah dasar (Permendikbud, 2014). Sujiono menyatakan bahwa pendidikan anak usia dini meliputi segala hal baik upaya maupun tindakan yang berikan oleh pendidik dan orang tua untuk memberikan stimulasi, bimbingan, perawatan dan pengasuhan pada anak usia dini sehingga tercipta suasana dan lingkungan yang memungkin anak dapat mengeksplorasi pengalaman, pengetahuan dan pemahaman terhadap pengalaman belajar yang telah diperoleh anak dari lingkungan, dengan cara mengamati, meniru, bereksperimen secara berulang-ulang dan melibatkan semua potensi dan kecerdasan anak (Sujiono, 2012). Pola pembelajaran anak usia dini di satuan-satuan PAUD yang sebelumnya dilakukan dengan pelibatan aktif dari pendidik dan peserta didik melalui kegiatan bermain sambil belajar karena adanya coronavirus disease atau covid-19, semua aktivitas itu di rumahkan. Pemberian stimulasi perkembangan untuk perkembangan kognitif, bahasa, fisik motorik, sosial emosional, agama dan moral serta seni harus dilakukan di rumah masing-masing peserta didik. Pemberian stimulasi terhadap perkembangan anak usia dini dilakukan secara efektif dan efisien oleh pendidik PAUD menggunakan beragam media sebagai sarana pembelajaran dengan prinsip bahwa aktivitas utama anak bermain sambil belajar. Zaini menyatakan bahwa metode pembelajaran untuk anak usia dini adalah bermain (Zaini, 2015). Bermain sebagai aktivitas utama anak untuk mempelajari dan menyelami pengalaman yang dimiliki agar anak memiliki pengetahuan baru.

Papalia dan Feldman mengemukakan bahwa bermain sebagai kegiatan dan aktivitas anak usia dini memiliki andil terhadap aspek-aspek perkembangan anak usia dini. Melalui aktivitas bermain anak menguasai fungsi-fungsi tubuh dengan baik, mengkoordinasi antara mata dengan gerakannya, melatih otot-otot anak, membuat keputusan dan mendapatkan keahlian/kemampuan baru (Papalia \& Feldman, 2015). Lebih lanjut dijelaskan oleh Hurlock yang mengemukakan bahwa pada masa awal kanak-kanak dikenal dengan sebutan tahap mainan karena semua rutinitas bermain yang mainkan oleh anak usia dini menggunakan mainan (Hurlock, 1980). Suyadi dan Ulfah mengemukakan bahwa dengan bermain anak dilibatkan untuk bereksplorasi, mendeteksi dan menggunakan media berupa benda-benda yang ada di sekitarnya (Suyadi dan Ulfah, 2013). Bermain merupakan strategi utama pendidik anak usia dini di lembaga-lembaga pendidikan untuk seluruh aktivitas pembelajaran anak usia dini.

Sebuah kegiatan bermain yang dirancang dengan baik dan cermat guna mencapai tujuan pembelajaran serta memfokuskan aktivitasnya pada salah satu aspek perkembangan anak akan sangat baik dan efektif untuk stimulasi perkembangan anak. Jawati mengemukakan bahwa kemampuan kognitif anak usia 5-6 tahun dapat ditingkatkan dengan 
permainan ludo geometri (Jawati, 2013). Sedangkan Hewi dan Surpida mengemukakan bahwa permainan dadu sangat baik untuk pengembangan perilaku prososial anak (Hewi dan Surpida, 2019). Tatminingsih menyatakan bahwa model pembelajaran berbasis permainan komprehensif dapat meningkatkan kemampuan kognitif anak. Model permainan komprehensif dapat diterapkan pada model sentra maupun kelompok (Tatminingsih, 2019). Ayu mengemukakan bahwa kemampuan kognitif anak dalam kegiatan membilang dapat ditingkatkan melalui metode bermain media kartu angka (Ayu, 2016). Berdasarkan asumsiasumsi yang telah dikemukakan menuntun pada pemikiran bahwa bermain untuk anak usia dini di lembaga-lembaga PAUD harus dengan perencanaan dan penggunaan media yang sesuai dengan perkembangan anak. Seluruh pendidik PAUD sebagai pengelola proses pembelajaran semestinya mampu menggunakan dan memilih media yang sesuai dengan aspek perkembangan yang akan diberikan stimulasi untuk dimaksimalkan perkembangannya.

Pendidik anak usia dini menurut peraturan menteri pendidikan dan kebudayaan nomor 137 tentang standar nasional pendidikan anak usia dini terdiri atas guru PAUD, guru pendamping dan guru pendamping muda yang penentuan statusnya apakah guru utama atau guru pendamping didasarkan pada kualifikasi pendidikan dari guru yang bersangkutan. Sebagai tenaga profesional pendidik anak usia dini memiliki tugas utama untuk merencanakan pembelajaran, melaksanakan dan menilai hasil pembelajaran serta melakukan pembimbingan, pelatihan, pengasuhan dan perlindungan (Dewi dan Suryana, 2020). Tugas perencanaan pendidik anak usia dini berhubungan dengan penyusunan rencana pembelajaran harian dan mingguan serta rencana pembelajaran semester, sementara pelaksanaan pembelajaran dilakukan melalui kegiatan bermain dan penilaian hasil pembelajaran dilakukan untuk melihat capaian aspek perkembangan anak usia dini setelah dilakukan pembelajaran.

Pendidik anak usia dini era covid-19 berbeda secara tugas dan fungsi dengan pendidik PAUD pada situasi seperti biasanya yaitu pendidik anak usia dini yang selama ada di lembaga-lembaga PAUD ada guru utama atau guru PAUD, guru pendamping dan pendamping muda. Namun karena coronavirus disease peran pendidik PAUD diganti atau beralih pada orang tua peserta didik masing-masing. Hal ini karena adanya himbauan dari pemerintah dan pemangku kebijakan pendidikan tentang social dan physical distancing serta pembelajaran daring dari rumah masing-masing peserta didik maka guru PAUD diperankan oleh seluruh orang tua peserta didik. Pendidik PAUD yaitu guru utama, guru pendamping atau pendamping muda yang selama ini tekun, ulet dan kreatif dalam melakukan stimulasi perkembangan untuk perkembangan kognitif, bahasa, fisik motorik, sosial emosional, agama dan moral serta seni hanya berfungsi sebagai perencana pembelajaran yang akan dilakukan serta penilai hasil pembelajaran yang dikomunikasikan melalui grup what's up lembaga PAUD.

Aspek perkembangan yang diberi stimulasi oleh orang tua peserta didik di rumah sesuai atau sama dengan aspek perkembangan yang dikembangkan oleh pendidik PAUD di lembaga pendidikan anak usia dini yaitu mulai dari aspek perkembangan kognitif, fisik motorik, bahasa, agama dan moral, seni dan sosial emosional. Hal ini sesuai dengan ketentuan dalam peraturan menteri pendidikan dan kebudayaan nomor 137 tentang standar nasional pendidikan anak usia dini yang menyatakan bahwa standar tingkat pencapaian perkembangan anak sebagai kemampuan yang harus dicapai oleh anak usia dini pada lima aspek perkembangan yaitu nilai agama dan moral, fisik motorik, kognitif, bahasa, sosial emosional dan seni (Permendikbud, 2014). Namun demikian selama ini persepsi orang tua tentang pembelajaran anak usia dini yang identik dengan anak harus bisa membaca atau mengenal huruf abjad dari secara keseluruhan dan anak mampu menulis secara baik dan benar tetap nampak pada pelaksanaan praktek belajar di rumah sehingga aspek perkembangan yang mendapatkan stimulasi perkembangan yang intens adalah kognitif dan bahasa serta aspek agama. 
Pelaksanaan pembelajaran untuk anak usia dini yang dilakukan oleh pendidik yaitu guru PAUD sebagai perencana kegiatan dan penilai hasil pembelajaran. Sementara untuk pelaksanaan pembelajaran diperankan atau dilakukan oleh orang tua (pendidik) di rumah masing-masing peserta didik tetap menggunakan prinsip bermain sambil belajar. Kegiatan bermain anak usia dini sebelumnya selalu bersama guru dan rekan-rekan sejawatnya yaitu peserta didik lainnya di satuan PAUD karena adanya coronavirus disease atau covid-19 kegiatan bermain anak beralih dilakukan bersama dengan orang-orang terdekat anak yaitu orang tua dan anggota keluarga yang lain. Mulyasa menyatakan bahwa permainan untuk anak usia dini sebagai metode pembelajaran terdapat beberapa jenis antara lain bermain sosial, bermain dengan benda dan bermain peran (Mulyasa, 2012). Pelaksanaan aktivitas bermain yang dilakukan di rumah untuk anak usia dini lebih dekat pada jenis metode bermain dengan benda dan bermain peran yaitu aktivitas bermain dengan memanfaatkan benda-benda di sekitar anak sebagai sarana bermain dan aktivitas bermain yang dimainkan anak berlakon sebagai orang lain.

Perkembangan kognitif sebagai salah satu aspek perkembangan yang harus diberikan stimulasi pada anak usia dini memiliki beberapa indikator yang terbagi dalam tiga lingkup aspek perkembangan yaitu pertama, belajar dan pemecahan masalah; kedua, berfikir logis dan ketiga, berfikir simbolik. Sedangkan untuk aspek perkembangan bahasa memiliki tiga lingkup aspek perkembangan yaitu pertama, memahami bahasa; kedua, mengungkapkan bahasa dan ketiga, keaksaraan (Permendikbud, 2014). Seluruh lingkup aspek perkembangan kognitif maupun bahasa memiliki indikator perkembangan masing-masing yang beragam dan berbeda-beda antara satu indikator aspek dengan yang lainnya. Fardiah, Muwarni dan Dhieni menyatakan bahwa kemampuan kognitif dapat ditingkatkan dengan metode pembelajaran sains melalui bermain sensormotorik (Fardiah, Murwani dan Dhieni, 2020).

Penelitian ini memfokuskan kajian pada perkembangan kognitif anak usia dini yaitu lingkup perkembangan berfikis logis yaitu mengenal sebab akibat, perbedaan, klasifikasi, pola, inisiatif anak dan kemampuan membuat perencanaan anak. Kemampuan berfikir logis pada anak usia dini menurut Permatasari, Rohaeti dan Westhisi mengemukakan bahwa kemampuan berfikir logis anak usia dini dapat ditingkatkan melalui penggunaan metode bernyanyi (Permatsari, Rohaeti dan Westhisi, 2019). Yunita, Meilanie dan Fahrurrozi mengemukakan bahwa kemampuan berfikir kritis anak dapat ditingkatkan melalui pendekatan saintifik (Yunita, Meilanie \& Fahrurrozi, 2019). Joni menyatakan bahwa kemampuan kognifit anak dapat ditingkatkan melalui permainan dadu (Joni, 2016). Begitu juga dengan temuan dari hasil penelitian Retnaningrum yang mengemukakan bahwa media bermain memancing dapat meningkatkan perkembangan kognitif anak (Retnaningrum, 2016). Berdasarkan temuan-temuan dari peneliti terdahulu yang telah dikemukakan tentang perkembangan kognitif dapat pahami bahwa kegiatan bermain yang dilakukan dalam pembelajaran untuk anak usia dini sangat baik untuk pengembangan aspek kognitif baik secara keseluruhan maupun untuk satu lingkup dari aspek kognitif.

\section{METODOLOGI}

Peneliti menggunakan pendekatan kualitatif dalam penelitian ini dengan metode penelitian studi kasus. Creswell menyatakan bahwa studi kasus merupakan metode penelitian yang menyelediki secara cermat suatu peristiwa, suatu program, aktivitas sekelompok orang dan dibatasi oleh waktu serta aktivitas informan (Creswell, 2015). Sementara Denzin dan Lincoln mengemukakan bahwa metode kasus merupakan metode penelitian pribadi dan kajian tentang pengalaman individu yang unik dank has untuk mewakili suatu kasus (Denzin \& Lincoln, 2009). Penggunaan metode ini digunakan untuk memperoleh pemahaman mendalam tentang strategi pendidik anak usia dini era covid-19 dalam menumbuhkan dan mengembangkan kemampuan berfikir logis anak. Selanjutnya, hasil temuan penelitian dideskripsikan dengan bahasa yang tepat dan sistematis sesuai dengan fakta-fakta lapangan yang ada dalam penelitian. 
Penelitian dilakukan di PAUD Sultan Qaimuddin Kendari merupakan labschool prodi Pendidikan Islam Anak Usia Dini Institut Agama Islam Negeri Kendari yang beralamat di Tipulu Kota Kendari (kampus 1 IAIN Kendari). Adapun waktu pelaksanaan penelitian yaitu pada bulan maret dan april 2020 atau diberlakukannya larangan untuk berkumpul (social distancing) dimana seluruh pelaksanaan pembelajaran pada seluruh jenjang pendidikan dihimbau untuk dilakukan dari rumah (daring) peserta didik. Sementara subjek penelitian ditentukan oleh peneliti secara purposive sampling yaitu anak kelompok A PAUD Sultan Qaimuddin Kendari yang diberikan stimulasi perkembangan oleh orang tuanya masing-masing di rumah kemudian dikontrol dan dilaporkan hasil pelaksanaannya melalui media sosial (what's up) grup lembaga PAUD.

Wawancara dan dokumentasi adalah teknik utama untuk mengumpulkan data dalam penelitian. Alasan penggunaan teknik wawancara dan dokumentasi dalam penelitian yaitu adanya larangan untuk melakukan interaksi secara dekat dengan orang lain social dan physical distancing yang tidak memungkin peneliti menggunakan teknik pengumpulan data lainnya. Data yang terkumpul selanjutnya dianalisis dengan menggunakan langkah-langkah yaitu reduksi data, penyajian data, penarikan kesimpulan dan verifikasi. Adapun desain penelitian seperti gambar di bawah ini:

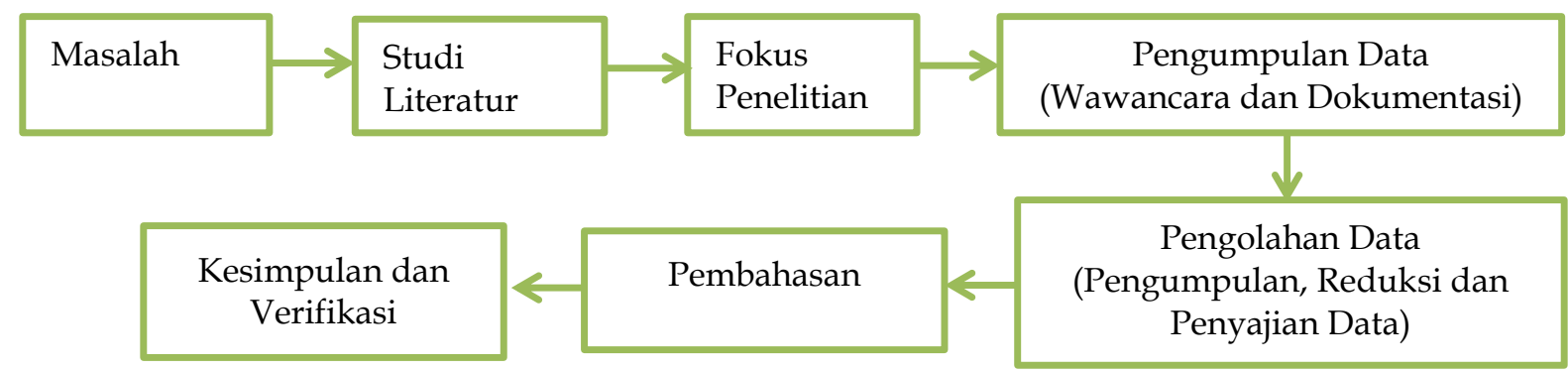

Gambar 1. Desain Penelitian

\section{HASIL DAN PEMBAHASAN}

Stimulasi Perkembangan kognitif sebagai salah satu aspek perkembangan pada anak usia dini dilakukan oleh seluruh pendidik di lembaga-lembaga PAUD di seluruh Indonesia. PAUD sultan qaimuddin kendari selaku lembaga pendidikan anak usia dini yang memberikan layanan untuk anak usia empat sampai enam tahun juga secara intens dan sistematis memberikan stimulasi perkembangan anak usia dini pada aspek-aspek yang telah ditentukan oleh standar nasional pendidikan anak usia dini terdiri dari aspek kognitif, fisik motorik, sosial emosional, bahasa, agama dan moral serta seni.

Pemberian stimulasi perkembangan kognitif pada anak usia dini di PAUD sultan qaimuddin kendari dilakukan dengan berpedoman pada indikator capaian perkembangan yang ada dalam Permendikbud nomor 137 tahun 2014 tentang standar nasional pendidikan anak usia dini. Perkembangan kognitif dalam standar PAUD diberikan lingkup perkembangan antara lain belajar dan pemecahan masalah, berfikir logis dan berfikir simbolik dengan indikator capaian masing-masing perkembangan yang berbeda. Berikut indikator perkembangan kognitif dan lingkup perkembangannya serta indikator masingmasing lingkup perkembangan sesuai dengan Permendikbud 137 tahun 2014 sebagai berikut: 
Tabel 1. Indikator perkembangan kognitif

\begin{tabular}{ll}
\hline $\begin{array}{l}\text { Lingkup Perkembangan } \\
\text { Kognitif }\end{array}$ & \multicolumn{1}{c}{ Capaian Perkembangan Anak Usia 4-5 Tahun } \\
\hline Belajar dan Pemcahan & - Mengenal benda berdasarkan fungsinya \\
Masalah & - Menggunakan benda-benda sebagai permainan simbolik \\
& - Mengenal konsep sederhana dalam kehidupan sehari-hari \\
& - Mengetahui konsep banyak dan sedikit \\
& - Mengkreasikan sesuatu dengan ide sendiri \\
& - Mengamati benda dan gejala dengan rasa ingin tahu \\
& - Mengenal pola kegiatan dan menyadari pentingnya waktu \\
& - Memahami kedudukannya dalam keluarga atau lingkungan \\
& social \\
\hline Berfikir Logis & Mengklasifikasi benda berdasarkan fungsi, bentuk, warna \\
& atau ukuran \\
& - Mengenal sebab akibat yang terkait dirinya \\
& - Mengklasifikan benda ke dalam kelompok yang sama \\
& - Mengenal pola \\
& - Mengurutkan benda berdasarkan ukuran dan warna \\
\hline Berfikir Simbolik & - Membilang banyak benda satu sampai sepuluh \\
& - Mengenal konsep bilangan \\
& - Mengenal lambing bilangan \\
& - Mengenal lambing huruf \\
\hline
\end{tabular}

Berdasarkan lingkup perkembangan kognitif dan indikator capaiannya yang telah dikemukakan selanjutnya peneliti menentukan bahwa lingkup perkembangan berfikir logis akan dijadikan fokus untuk diberi pengamatan yang konsen saat anak telah melakukan pembelajaran di rumah serta cara pendidik PAUD di rumah (orang tua anak) memberikan layanan stimulasi perkembangan. Walaupun tidak semua orang tua dapat memberikan stimulasi perkembangan seperti komunikasi yang disampaikan oleh guru PAUD. Irma, Nisa dan Sururiyah menyatakan bahwa keterlibatan orang tua dalam mendidik anak dalam pendidikan anak usia dini dipengaruhi oleh status social, bentuk keluarga, tahap perkembangan keluarga dan model peran (Irma, Nisa \& Sururiyah, 2019).

Adanya pandemi coronavirus disease atau covid-19 menyebabkan pemberian stimulasi perkembangan di PAUD sultan qaimuddin kendari mengalami perubahan dari sebelumnya berpusat pada guru dan peserta didik melalui kegiatan bermain sambil belajar kemudian beralih pada orang tua peserta didik. Hal ini sesuai dengan kebijakan kementerian pendidikan dan kebudayaan melalui surat edaran nomor 4 tahun 2020 tentang pelaksanaan kebijakan pendidikan dalam masa darurat penyebaran coronavirus disease (Covid-19). Kebijakan kemendikbud membawa perubahan pada pelaksanaan pembelajaran di seluruh jenjang pendidikan baik jenjang pendidikan tinggi, pendidikan menengah, pendidikan dasar, maupun pendidikan anak usia dini. Perubahan pola dan pelaksanaan pendidikan juga berdampak pada strategi pendidik dalam memberikan materi dan pembelajaran untuk peserta didik.

Kegiatan pembelajaran di rumah oleh orang tua peserta didik sebagai pendidik menjadi sesuatu yang menarik sekaligus menantang. Pelaksanaan pembelajaran di rumah dimana orang tua berperan sebagai pendidik diarahkan tidak boleh hanya berfokus pada capaian kurikulum untuk kenaikan kelas maupun kelulusan akhir peserta didik, tetapi pembelajaran harus diarahkan pada pemberian pengalaman belajar yang bermakna bagi peserta didik. Fokus materi yang dituntut pada siswa sesuai dengan standar kompetensi dan kompetensi dasar dilakukan penyesuaian dimana fokusnya pada arah pendidikan kecakapan hidup antara lain mengenai penyebaran corona ke beberapa negara atau benua bahkan global (pandemi) tanpa terlalu berfikir tentang materi yang kaku sesuai silabus kurikulum yang ada. Hal yang sama pada aktivitas dan tugas pembelajaran peserta didik yang sebelumnya kaku yaitu harus sesuai tuntutan standar kompetensi yang ada. Dengan 
Kebijakan ini dilakukan reorientasi pembelajaran dengan aktivitas yang bervariasi antarsiswa tergantung minat dan kondisi masing-masing dengan mempertimbangkan kesenjangan akses/fasilitas belajar tempat masing-masing peserta didik. begitu juga dengan produk hasil belajar jika sebelumnya berfokus pada penguasaan pengetahuan, keterampilan dan sikap dengan memberikan skor/ nilai berupa angka secara kuantitatif, kebijakan ini mengubah hal tersebut pada umpan balik yang bersifat kualitatif yang berguna kepada pendidik/guru tanpa harus memusingkan untuk memberikan skor kuantitatif pada peserta didik.

Seluruh point dalam kebijakan tentang pelaksanaan pendidikan selama masa coronavirus disease sangat sesuai dengan prinsip-prinsip dalam pembelajaran di pendidikan anak usia dini yang pada sisi materi atau tema dipilih dengan menggunakan kriteria kedekatan, kesederhanaan, kemenarikan dan keinsidentalan. Materi tentang pandemi covid19 pada awalnya tidak ada dalam rencana pembelajaran semester di PAUD sultan qaimuddin kendari, namun dengan berpedoman pada prinsip pemilihan tema yang ada di PAUD maka tema covid-19 di masukkan sebagai salah satu tema yang harus dipelajari oleh anak usia dini.

Pendidik anak usia dini dalam memberikan stimulasi perkembangan untuk peserta didik pada masa pandemi covid-19 bekerja sama dengan orang tua peserta didik. Hal ini berarti bahwa sebutan pendidik (guru) PAUD tidak terbatas hanya guru PAUD seperti biasa tetapi sebutan pendidik anak usia dini juga melekat pada orang tua atau ungkapan dalam pendidikan bahwa orang tua adalah pendidik pertama dan utama bagi anak sangat terasa karena adanya masalah coronavirus disease. Wahy menyatakan bahwa keluarga sebagai basis pendidikan pertama dan utama untuk anak sebelum mendapatkan pendidikan formal (Wahy, 2012). Hewi, Saleh dan Wahyuni menyatakan bahwa pengalaman hidup yang berbeda-beda antara orang tua yang satu dengan lainnya menyebabkan perbedaan dalam memberikan pengasuhan (pendidikan) untuk anak (Hewi, Saleh dan Wahyuni, 2019). Sehingga untuk keseragaman dalam pemberian stimulasi perkembangan bagi anak usia diperlukan kerjasama antara guru PAUD di lembaga pendidikan anak usia dini dengan orang tua peserta didik atau pendidik anak usia dini era covid-19. Guru PAUD sebagai perencana dan penilai hasil pembelajaran sedangkan pendidik PAUD di rumah (orang tua) sebagai pelaksana rencana pembelajaran dari guru PAUD.

Kerja sama antara kedua pendidik yang dimaksud yaitu guru PAUD dan orang tua peserta didik dilakukan agar stimulasi perkembangan untuk semua anak usia dini dalam satuan PAUD dapat sama atau seragam. Guru PAUD melakukan perencanaan pembelajaran dengan menyusun rencana pembelajaran harian yang selanjutnya diberikan kepada orang tua peserta didik dengan didatangi secara langsung di rumah masing-masing peserta didik dan diberikan melalui soft file yang dikirim di media social (what's up) orang tua anak usia dini dan kemudian untuk dilaksanakan pembelajaran di rumah. Hasil pembelajaran akan dilaporkan oleh orang tua selaku pendidik PAUD di rumah melalui rekaman kegiatan dan dokumentasi hasil kerja anak selama proses pembelajaran melalui media social (what's up) grup satuan PAUD.

Hasil rekaman atau dokumentasi hasil karya yang dikirim oleh orang tua peserta didik selanjutnya dianalisis dan diberikan penilaian sesuai dengan konsep penilaian yang ada yaitu kegiatan yang dilakukan oleh anak dalam laporan itu termaksud pada aspek perkembangan apa serta pada kategori perkembangan yang bagaimana misalnya berkembang sangat baik, berkembang sesuai harapan atau mulai berkembang dan bahkan belum berkembang. Hasil penilaian kemudian dikomunikasi kepada orang tua peserta didik dengan menggunakan media social (what's up) secara pribadi antara orang tua dengan guru PAUD untuk ditindaklanjuti dengan dilakukan perbaikan pada pembelajaran selanjutnya. 
Berikut dokumen hasil pembelajaran yang dikirimkan oleh salah satu orang tua peserta didik;

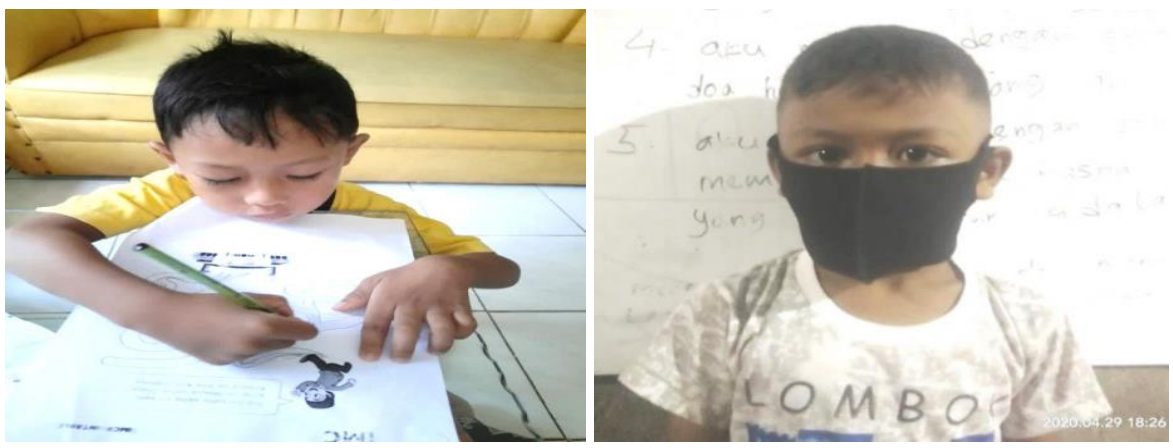

\section{Gambar 2. Dokumen Laporan Pembelajaran}

Dokumen hasil pembelajaran yang dilakukan di rumah menunjukkan bahwa anak mampu melakukan kegiatan bermain sambil belajar sesuai arahan pendidik PAUD di rumah (orang tua). Berdasarkan dokumen yang ada memperlihatkan kemampuan kognitif anak pada penguasaan konsep yaitu mengenal sebab akibat; anak pertama tidak membuat alur jalan/jejak untuk ke sekolah karena adanya virus corona tetapi hanya membuat alur jalan/jejak ke rumah; sementara anak kedua menunjukkan bahwa karena adanya covid-19 maka dalam melakukan aktivitas harus menggunakan masker agar terhindar dari penularan coronavirus disease. Sehingga dokumen hasil kegiatan pembelajaran di rumah menunjukkan bahwa anak usia dini berada pada kategori penilaian berkembang sangat baik untuk aspek perkembangan kognitifnya pada lingkup berfikir logis yaitu anak mampu mengenal sebab akibat menyangkut dirinya.

Pelaksanaan kegiatan pembelajaran di rumah dilakukan oleh pendidik PAUD (orang tua) secara singkat dapat dideskripsikan mengikuti langkah-langkah antara lain; pertama, kegiatan awal diawali dengan orang tua menyuruh anak membaca doa belajar lalu orang tua dan anak bernyanyi bersama lagu pagiku cerahku atau lagu-lagu lain telah dikuasai anak; kedua, kegiatan inti dilakukan sesuai dengan rencana pembelajaran yang dibuat oleh guru PAUD misalnya anak diminta untuk mewarnai gambar, menggunting sesuai pola gambar yang diberikan, bercerita, berdiskusi tentang kegiatan belajar di rumah; mengapa tidak sekolah, mengapa kalau keluar dari rumah harus menggunakan masker, serta kegiatankegiatan lainnya; ketiga, kegiatan penutup dilakukan dengan cara anak menunjukkan hasil karya atau aktivitasnya untuk direkam atau di foto oleh orang tua yang selanjutnya dilaporkan pada guru PAUD dengan cara dikirim di media social (what's up) grup satuan PAUD.

Strategi pendidik PAUD di rumah (orang tua) dalam melakukan pemberian stimulasi perkembangan yaitu menggunakan strategi diskusi (percakapan/tanya jawab) dan keteladanan. Strategi diskusi (percakapan/tanya jawab) digunakan untuk mengkomunikasikan tema atau topik bahasan kepada anak dilakukan menanyakan apakah anak telah mengetahui sebelumnya topik bahasan yang akan dipelajari, misalnya topik bahasan "corona", anak diminta untuk menyampaikan apa itu corona, mengapa belajar dilakukan di rumah bukan di sekolah, mengapa kalau keluar dari rumah harus menggunakan masker; dengan mengajak anak bercakap-cakap tercipta interaksi yang menyenangkan antara pendidik dengan anak sehingga konsep yang ingin disampaikan dalam topik bahasan tentang corona bisa dipahami oleh anak. Strategi keteladanan digunakan oleh pendidik PAUD di rumah untuk memberikan contoh terlebih dahulu kepada anak dalam melakukan sesuatu sebelum anak sendiri yang melakukannya.

Materi tentang covid-19 diberikan kepada anak usia dini untuk memberikan pemahaman tentang kondisi saat ini yaitu pembelajaran dilakukan di rumah. Materi tentang coronavirus disease sangat cocok untuk pengembangan kemampuan kognitif anak usia dini 
utamanya pada lingkup kemampuan berfikir logis. Stimulasi perkembangan diberikan pada anak usia dini oleh pendidik (orang tua) selama masa darurat covid-19 melalui kegiatan pembelajaran yang menyenangkan dengan memanfaatkan tepukan dan nyanyian. Miranti, Engliana dan Hapsari menyatakan bahwa penggunaan media lagu adalah alternatif pada kegiatan pembelajaran agar menyenangkan, ceria dan mudah dipahami, media lagu memiliki pengaruh dalam mengembangkan kemampuan kosakata bagi siswa-siswi di PAUD (Miranti, Engliana \& Hapsari, 2015). Kamtini dan Sitompul mengemukakan bahwa metode bernyanyi berpengaruh signifikan terhadap kemampuan mengingat huruf dan angka anak usia 5-6 tahun (Kamtini dan Sitompul, 2020). Hal ini berarti bahwa dengan tepukan dan nyanyian akan dapat mengembangkan kognitif (kemampuan berfikir logis) karena perkembangan anak usia dini terjadi secara holistik integratif. Melalui strategi diskusi (percapakan/tanya jawab) dan keteladanan anak diajak untuk memahami mengapa sekolah di rumah, mengapa keluar rumah harus menggunakan masker, kenapa tidak bisa bermain di luar rumah. penggunaan strategi ini membuat anak mampu memahami semua hal itu sampai mampu membuat tepukan dan lagu tentang corona. Hal ini berarti bahwa anak mampu mengenal sebab akibat yang merupakan indikator capaian perkembangan kognitif pada lingkup berfikir logis.

\section{SIMPULAN}

Strategi pendidik anak usia dini era covid-19 yaitu pelibatan orang tua pada stimulasi perkembangan anak usia dini. Guru PAUD di sekolah melakukan dua tugas pokok sebagai guru yaitu perencana dan penilai hasil perkembangan anak usia dini sementara pendidik PAUD di rumah (orang tua) berfungsi sebagai pelaksana pembelajaran dengan memanfaatkan strategi diskusi (percapakan/tanya jawab) dan keteladanan yaitu anak diajak untuk memahami mengapa sekolah di rumah, mengapa keluar rumah harus menggunakan masker, kenapa tidak bisa bermain di luar rumah. penggunaan strategi ini membuat anak mampu memahami semua hal itu dan mampu membuat tepukan dan lagu tentang covid-19. Hal ini berarti bahwa anak mampu mengenal sebab akibat yang merupakan indikator capaian perkembangan kognitif pada lingkup berfikir logis.

\section{UCAPAN TERIMAKASIH}

Ucapan terima kasih penulis sampaikan kepada pengelola PAUD Sultan Qaimuddin Kendari selaku labshool prodi pendidikan islam anak usia dini yang telah mengizinkan untuk dilakukannya penelitian ini. Penulis juga berterima kasih dan mengapresiasi Tim Editor Jurnal Obsesi yang pada masa darurat covid-19 memberikan priotas dan membebaskan seluruh biaya penerbitan untuk tulisan tentang pandemi coronavirus disease.

\section{DAFTAR PUSTAKA}

Ayu, C. (2016). Meningkatkan Kemampuan Kognitif Anak dalam Kegiatan Membilang dengan Metode Bermain Media Kartu Angka pada Anak Usia 4-5 Tahun di TK Taqifa Bangkinang. Jurnal Obsesi: Jurnal Pendidikan Anak Usia Dini, 2(2), 60-71. https:// doi.org/DOI : https://doi.org/10.31004/obsesi.v2i2.43

Creswell, J. W. (2015). Research Design Pendekatan Kualitatif, Kuantitatif, dan Mixed. Yogyakarta: Pustaka Pelajar.

Dewi, Iratna dan Suryana, D. (2020). Analisis Evaluasi Kinerja Pendidik Paud di PAUD Al Azhar Bukittinggi. Jurnal Obsesi: Jurnal Pendidikan Anak Usia Dini, 4(2), 1051-1059. https:// doi.org/DOI : https:// doi.org/10.31004/obsesi.v4i2.465

Fardiah, Murwani, Santosa dan Dhieni, N. (2020). Meningkatkan Kemampuan Kognitif Anak Usia Dini melalui Pembelajaran Sains. Jurnal Obsesi: Jurnal Pendidikan Anak Usia Dini, 4(1), 133-140. https:/ / doi.org/DOI : https:// doi.org/10.31004/obsesi.v4i1.254

Hewi, La, Muh. Saleh dan Wahyuni, R. (2019). Kelekatan (Attachment) Anak Usia Dini di Suku Laut Kabupaten Wakatobi. Jurnal Obsesi, 4(1), 406-415. https://doi.org/DOI: 
Strategi Pendidik Anak Usia Dini Era Covid-19 dalam Menumbuhkan Kemampuan Berfikir Logis

DOI: 10.31004/ obsesi.v5i1.530

\subsection{4/obsesi.v4i1.346}

Hewi, L. dan S. (2019). Permainan Dadu pada Pengembangan Perilaku Prososial Anak di RA An-Nur Kota Kendari. JECED : Journal of Early Childhood Education and Development, 1(2), 115-128. https:// doi.org/DOI: https://doi.org/10.15642/jeced.v1i2.468

Hurlock, E. B. (1980). Psikologi Perkembangan Suatu Pendekatan Sepanjang Rentang Kehidupan (Kelima). Jakarta: Erlangga.

Irma, C. N., Nisa, K., \& Sururiyah, S. K. (2019). Keterlibatan Orang Tua dalam Pendidikan Anak Usia Dini di TK Masyithoh 1 Purworejo. Jurnal Obsesi: Jurnal Pendidikan Anak Usia Dini, 214-224(3), 1. https:// doi.org/DOI: 10.31004/obsesi.v3i1.152

Jawati, R. (2013). Peningkatan Kemampuan Kognitif Anak Melalui Permainan Ludo Geometri di PAUD Habibul Ummi II. Spektrum: Jurnal Pendidikan Luar Sekolah (PLS), 1(1), 250-263. https://doi.org/10.24036/spektrumpls.v1i1.1537

https://doi.org/DOI :

Joni. (2016). Peningkatan Kemampuan Kognitif Anak dalam Kegiatan Berhitung dengan Permainan Dadu TK Mutiara Pekanbaru. Obsesi: Jurnal Pendidikan Anak Usia Dini, 2(1), 1-10. https://doi.org/DOI : https://doi.org/10.31004/obsesi.v2i1.44

Kamtini dan Sitompul, F. A. (2020). Pengaruh Metode Bernyanyi terhadap Kemampuan Mengingat Huruf dan Angka pada Anak Usia Dini. Jurnal Obsesi: Jurnal Pendidikan Anak Usia Dini, 4(1), 141-145. https:/ / doi.org/DOI: 10.31004/obsesi.v4i1.295

Kebudayaan, K. P. dan. Permen Dikbud Nomor 137 tentang Standar Nasional Pendidikan Anak Usia Dini. , (2014).

Miranti, Ira,. Engliana \& Hapsari, F. S. (2015). Penggunaan Media Lagu Anak-Anak Dalam Mengembangkan Kemampuan Kosakata Bahasa Inggris Siswa Di Paud. Faktor Jurnal Ilmiah Kependidikan, 2(2), 167-172.

Mulyasa. (2012). Manajemen PAUD. Bandung: Remaja Rosdakarya.

Norman K. Denzin \& Yvonna S. Lincoln (Eds.). (2009). Handbook Of Qualitative Research. In 1 (Dariyatno). Yogyakarta: Pustaka Pelajar.

Papalia, D. E. dan R. D. F. (2015). Menyelami Perkembangan Manusia. Jakarta: Salemba Humanika.

Permatsari, Dewiana, Rohaeti, Euis Eti Sharina dan Westhisi, M. (2019). Meningkatkan Kemampuan Berpikir Logis Anak Usia Dini Melalui Metode Bernyanyi Pada Anak Kelompok B. Jurnal Ceria, 2(6), 230-236. https://doi.org/DOI: http://dx.doi.org/10.22460/ceria.v2i5.p230-236

Retnaningrum, W. (2016). Peningkatan Perkembangan Kognitif Anak Usia Dini melalui Media Bermain Memancing. Jurnal Pendidikan Dan Pemberdayaan Masyarakat, 3(2), 207-218. https://doi.org/DOI:http:/ / dx.doi.org/10.21831/jppm.v3i2.11284

Sujiono, Y. N. (2012). Konsep Dasar Pendidikan Anak Usia Dini.

Suyadi dan Ulfah, M. (2013). Konsep Dasar PAUD. Bandung: Remaja Rosdakarya.

Tatminingsih, S. (2019). Alternatif Stimulasi Kemampuan Kognitif melalui Penerapan Model Pembelajaran Berbasis Permainan Komprehensif. Jurnal Obsesi: Jurnal Pendidikan Anak Usia Dini, 3(1), 183-190. https://doi.org/DOI : https://doi.org/10.31004/obsesi.v3i1.130

Wahy, H. (2012). Keluarga Sebagai Basis Pendidikan Pertama Dan Utama. Jurnal Ilmiah Didaktika, 12(2), 245-258. https://doi.org/DOI: http://dx.doi.org/10.22373/jid.v12i2.451

Yunita, H., Meilanie, S. M., \& F. (2019). Meningkatkan Kemampuan Berpikir Kritis melalui Pendekatan Saintifik. Jurnal Obsesi: Jurnal Pendidikan Anak Usia Dini, 3(2), 294-584. https:// doi.org/DOI : https:/ / doi.org/10.31004/obsesi.v3i2.228

Zaini, A. (2015). Bermain sebagai Metode untuk Pembelajaran Anak Usia Dini. Thufula: Jurnal Inovasi Pendidikan Guru Raudhatul Atfal, 3(1), 118-134. https://doi.org/DOI: http://dx.doi.org/10.21043/thufula.v3i1.4656 